\title{
Development of Mathematics Learning Model Based on a Metakognitif Approach with Student Character Involving Student Emotional Intelligence
}

\author{
Putri Su'aidah Pulungan ${ }^{1}$, Nurul Husna Lubis ${ }^{2}$, Dr. KMS. M. Amin Fauzi, M.Pd ${ }^{3}$ \\ ${ }^{1,2,3}$ Mathematics Education Program, Medan State University (UNIMED)
}

\begin{abstract}
The long term goal of this research is to produce a mathematics learning model that involves emotional intellegence to build student character. Development of learning model conducted in this research follow the development model of Plomp consist of 5 phase: (a) initial review, (b) design, (c) realisation (construction), (d) test, evaluation, and revision and (e) implementation.
\end{abstract}

Keywords: Learning Model, Character, Emotional Intelligence

\section{Introduction}

Wellman (1985) states that: Metacognition is a form of cognition, second or higher order thinking processes involving active control over cognitive processes. This can be simply defined as thinking about thinking or "cognition of a person about cognition" Metacognition as a form of cognition, or immunization process involves a higher level of thinking, involving control of cognitive activity.

Flavell \& Brown in stating that metacognition is knowledge (knowledge) and regulation (regulation) on a person's cognitive activities in the learning process. While Moore (2004) states that: Metacognition refers to a person's understanding of his knowledge, so that a deep understanding of his knowledge will reflect his effective use or clear description of the knowledge in question. This shows that knowledge-cognition is one's consciousness of what he or she really knows and the cognitions are how one organizes his cognisive activity effectively. Therefore, knowledge-cognition contains declarative, procedural, and conditional knowledge, while cognitions include planning, prediction, monitoring, testing, revision, checking, and evaluation.

At the formal stage of thinking, the child is able to reason scientifically, testing the hypothesis he makes, and they are able to reflect a result through a well-constructed understanding. At this time, they began to develop reasoning and logic to solve problems (Wadsworth, 1984). The level of formal operational thinking is essentially metacognition, since formal operations involve thinking about propositions, hypotheses and imagining all possible cognitive objects (Flavell, 1985).

Facts show that in a very micro scale, the process of learning mathematics in almost all levels and types of education are still concentrated on the circumstances associated with the left brain's ability of learners. Conversely the ability of the right brain has not been developed, even almost never developed a serious and systematic. This condition causes the mathematics education in particular is only able to produce beings who lack self-awareness, less creative, less independent, and less able to communicate seamlessly with the physical environment and social life. Mathematics education is expected to contribute to the empowerment of all citizens become religious, knowledge and skills to live. This hope will be achieved when the potential of the right brain function optimally together with high emotional intelligence as well. The importance of character and emotional intelligence need to be considered in the learning, the authors conducted research on the development of learning mathematics model based on student character involving emotional intelligence student teachers. The results of this research are Mathematics Learning Model Based on Student Character Involving Student Emotional Intelligence on Methodological Research in Mathematics Education course valid, practical and effective. This research was conducted to answer the question of how the characteristics of Mathematics Learning Model Based on Student Character Involving Student Emotional Intelligence?

\section{Literature Review}

Understanding of the character according to the Ministry of National Education Language Centre is congenital, heart, soul, personality, character, behaviour, personality, triat, nature, temperament, character (in Suyanto, 2009). According Tadkiroatun Musfiroh (in Fuadi, 2011), a character refers to a set of attitudes, behavior, motivation and skills. Character is a personality that includes, among others, honesty of someone who usually has to do with the properties that are relatively fixed. Thus the character of the values of human behavior associated with the Almighty God, ourselves, our fellow human beings, the environment, and nationality embodied in thoughts, attitudes, feelings, words, and actions based on religious norms, laws, manners, culture, and customs.

\subsection{Emotional Intelligence}

Shapiro (1999: 5) argues that the term "emotional intelligence" was first introduced by psychologist Peter Salovey (1990) from Harvard University and John Mayer of the University of New Hampshire. They explain the emotional quality that is essential to success. The quality of these qualities among others: empathy, like others, express and understand the feelings, the personal problem-solving skills, anger control, perseverance, self-reliance, solidarity, adaptability, friendliness, and respect. Goleman (2000) 


\section{International Journal of Science and Research (IJSR) \\ ISSN (Online): 2319-7064}

Index Copernicus Value (2015): 78.96 | Impact Factor (2015): 6.391

suggested aspects of Emotional Intelligence (EI). Emotional Intelligence aspects described as follows (1) Emotional SelfAwareness (2) Empathy, reading emotions, (3) Establishing a relationship. It can be concluded that Emotional Intelligence is the ability to recognize your feelings and the feelings of others, the ability to motivate oneself, the ability to manage emotions well in ourselves and in association with others. Emotional intelligence includes the differnet ability and complementary to the purely cognitive abilities that have been previously known, namely the intelligence of the academic / intellectual / rational (IQ). Although a high IQ but low EI, usually not much help in almost all aspects of life. IQ and EI reveal the differnt activity in brain. IQ is based on the work of the neocortex, which is a layer in developing the latest evolution in the upper part of the brain.

Emotional intelligence is a person's ability to innovate in synergy with the work team to achieve the goals of the organization or group together; skills of emotional intelligence involves skill in managing one's self and others; social skills of emotional intelligence skills in managing labor relations and interaction in the dynamics of life. Here, one is not enough to just have a feeling but demanded also to learn to acknowledge, respect your feelings, the feelings of others in accepting the opinion properly and appropriately. If emotional intelligence is associated with modern life, the emotional intelligence plays an important role for the success of one's career, in the broad sense is very influential to success through life. Under normal circumstances, the routine activity of a person's emotions can not be observed. But emotions can emerge and be observed from facial expressions, tone of voice, facial expression, body language. This emotional expression, can be seen when the relationships with others and need each other.

\subsection{Character and Emotional Intelligence}

Emotional intelligence is not based on intelligence of a child but on a former so-called "character" or "personal characteristics". The very latest research found that social and emotional skills are more important to the success of life rather than intellectual ability. Students are unique individuals who have the potential and experience the growing process, where in the process of development, it requires that the nature and pattern is not determined by the educators (supervisor), but by the students themselves. Cooper and Sawaf (2001) revealed that if the power that drives intelligence in aspects of life until the end of the 20th century is IQ, it is based on proof that more and more in the early 21 st century, which will be instrumental is EI and its relevant forms practical intelligence and creative other. Emotions, as well as body and mind, contains the history of his life, his experience, his deep understanding and relationships with other people in his life. Emotions include feelings of a person and the person entering the system in the form of energy that can be created at any time and can also be destroyed, but its still flowing. This energy is transformed into EI and these changes will impact on the work, life, and relationships. According to Goleman that cognitive abilities affect a person's emotional intelligence. Knowledge will affect the people around him, and he will become a model and a driving force in the organization. His ability can be monitored from its ability to lead and encourage people to work well. Able to control the feelings of themselves and others, and use those feelings to integrate thought and action. That is the feeling of one's influence on decisions or actions in work. A leader before deciding anything important inthe organization will combine his feelings, his knowledge, his experience and includes feelings of others. Aspects of Emotional Intellegence considered in this research those are motivate it self, take inisiative, resonsibility, kinship, and mutual trust, caring, ductility, and toughness. PMK2E model developed in this research is a blend Model Plomp (1997), Nieveen (1999), and Joyce, Weil and Shower (1992). The main objective of this research is to determine a mathematics learning model by considering the character-based emotional intelligence. Joyce and Weil (Suparno, 2000) suggested that one strategy for learning as a learning models (Models of Teaching) can be grouped into four families / clump, the clumps social, clumps of process information, clumps personal, and clumps of system behavior or behavioral system. At this approach complex tasks that are broken down into more specific tasks that can be are owned by the students. Mathematics learning model that will be developed in this research refers to the learning model proposed by Joice, Weil and Shower (1992) as noted above. The stages of the stages or phases of a phase that will be pursued in the process of developing a model that you want to follow the way of phasing presented by Plomp (1997). Arends (1997) suggested that the learning model oriented learning approach that will be used, as well as the learning objectives, the steps of learning, learning environment, and classroom management. Characteristics of learning models according to Arend, includes four things: (1) rational theoretical arranged logically by the developer,

(2) the rationale of the objectives to be achieved in learning,

(3) forms of teaching activities necessary to support Implementation of model effectively, and (4) the atmosphere of learning environment that can support the achievement of learning objectives.

\section{Method}

\subsection{Procedure}

Here are respectively described activities performed at each phase of development.

1) Phase-1 Initial Review Initial review phase of PMK2E Model development consist of two things, namely initial investigation about learning model and learning support instrument.

2) Phase-2 Design In this Phase-2 was designed Mathematics Learning Model based on student Character involving student Emotional Intelligence. Activity in this Phase-2 includes (a) designing syntax of the learning that takes into account the student emotional intelligence, (b) designing social systems or the learning environment, the situation or the rules that apply in the PMK2E Model, (c) determining the support system, (e ) preparing the effect of learning, both instructional effect and nurturant effect. b. Designing Learning Tool In this Phase-2 supports tool that is designed in accordance with the draft of PMK2E Model. The tool are designed, that the lecturer guideline book, and student guideline book.

3) Phase-3 Realisation a. Realisation of Learning Model In this phase- 3 is made or created a learning model as a 


\section{International Journal of Science and Research (IJSR) \\ ISSN (Online): 2319-7064}

Index Copernicus Value (2015): 78.96 | Impact Factor (2015): 6.391

advance of design phase. Activity is done in this phase-1 is a realisation of model that have been designed in phase-2. b. Realisation of Learning Tool In this Phase-3 is made a learning tool that appropriate with PMK2E-1 Model in prottipe- 1 . The tools are made include lecturers guideline book, students guideline book and modules.

4) Phase-4 Test, Evaluation and Revition a. Test, Evaluation, and Revition of Learning Model Activities in this Phase-4 is focused on two things, namly validate and conduct field trials. For validation activities, which validates the Prototype-1 (PMK2E Model) as well as tools and instruments will be used). b. Conducted Field Trial Activity field trial aims to determine whether the learning model developed (prototype which has been declared valid) is practical and effective. In the activity of these trials used tools PMK2E learning model that has been through a validation process to a particular topic.

5) Phase-5 Implementation The activities conducted in this stage is (1) Designing the form of actual experimental research, by using the research design "pretest-posttest control group Design." (Tuckman, BW, 1972). (2) The final prototype learning tool supporting PMK2E models implemented in the field by conducting experimental research on the student as a prospective mathematics teachers 5th semester Cokroaminoto University of Palopo. Instrument The developed instruments are (1) model assessment sheet and assessment sheet of valid application, (2) observation sheets, (3) students questionnaire responses to components of learning activities, (4) evaluation sheet of learning achievement and (5) the format validation for each instrument.

\subsection{Strategy of Planning}

- Be Explicit: When walking students through your thinking process be as explicit as possible. Use words like, "I am thinking," pause, and point to your head. Being explicit helps students to understand exactly what you are doing. When describing your thinking be as detailed as possible.

- Graphic Organizers: Using graphic organizers during metacognition is a great way to give students visual reinforcement of the thinking processes you are describing. If grade level appropriate, students can take notes.

- Planning: Metacognition as an instructional strategy takes planning. Teachers should actively plan and script out the behaviors they are trying to model. Think through all of the possible misconceptions and plan to address them before they come up.

\section{The Math Teacher}

- Math teachers have a nuanced job. They must teach the building blocks of math, such as number sense and operational skills, as well as boost students' ability to think about problems. They need to incorporate aspects of language, including reading and writing, into their subject and provide direct instruction on methods of exploration. Additionally, math teachers must motivate students to try and teach them to persevere when problems are challenging. Let's look at some of the best methods and strategies for a quality math program.

\section{Methods for Teaching Math}

- When we talk about a method of instruction, we mean how content is being taught. This runs the gamut from style of instruction - for example, lecture vs. hands-onto materials used. Here are some tried and true methods for teaching math:

\section{- Use Visuals}

- Many students need to see a lesson in addition to hearing it. While explaining an operation or skill, use a visual or graphic to help get the point across. This can be as simple as showing the lesson on a document camera or as savvy as using a video or other technology tool.

- Note that children do best when instruction is paired with a visual; using a visual as a stand-alone teaching device isn't always effective. Vary your usage to keep students engaged.

\section{- Make Connections}

- Our brains are machines that thrive on connections. In fact, long-term memory is a complicated web of neurons, or brain cells, banded together. To help students make sense of concepts, provide them with connections to the real world or previously taught lessons. Always begin a new lesson with a reminder of the last. For example, you might say, 'Yesterday, we learned about the numerator in fractions. Today, we'll take a closer look at the other part of a fraction: the denominator.'

- Also, pay close attention to how students react to the connections you make. For example, one group might understand best when you use board games as an example, while another group might react better to an example connected to sports.

\section{- Use Assessments}

- Math is typically a progression-based subject. Skills build one upon another, and the order in which they're taught is predetermined. Because of this, a math teacher doesn't have to think much about what to teach when, but it is necessary to use assessments to determine student understanding. Formative assessments, or informal assessments meant to check in on student learning and drive future instruction, should be used frequently. This can help teachers identify students who struggle and allow additional small group or one-on-one instruction.

- Formative assessments aren't usually taken for grades. Students need to feel comfortable with their exploration of a subject without fear of their performance being used for grading.

\section{- Focus on Strategies}

- As we'll talk about later, math is all about problemsolving using strategies. Sometimes, there's only one way to solve a problem, but many times there are multiple avenues to the answer. When teaching, model several strategies for understanding and exploring a concept. Encourage students to apply high-level skills when given problems and focus on the thought process involved in the solution. 


\section{International Journal of Science and Research (IJSR) \\ ISSN (Online): 2319-7064}

Index Copernicus Value (2015): 78.96 | Impact Factor (2015): 6.391

Table 1: Metacognitive Strategy

\begin{tabular}{|c|c|c|}
\hline Strategy & Definition & Benefit \\
\hline Rehearsal & Reciting items to be learned from a list & $\begin{array}{l}\text { Believed to influence the attention and } \\
\text { coding process. It does not seem to help } \\
\text { students connect current information with } \\
\text { prior knowledge }\end{array}$ \\
\hline Elaboration & Summarizing or paraphrasing & $\begin{array}{l}\text { Believed to improve a student's ability to } \\
\text { store information into the long-term } \\
\text { memory by building internal connections } \\
\text { between items to be learned and assisting } \\
\text { with the integration of new information } \\
\text { with prior knowledge }\end{array}$ \\
\hline Organization & Outlining & $\begin{array}{l}\text { Helps leamers select appropriate } \\
\text { information and make the connections to } \\
\text { be leamed }\end{array}$ \\
\hline Analyzing & Problem-solving, critical thinking & $\begin{array}{l}\text { Assists students with applying previous } \\
\text { knowledge to new situations in order to } \\
\text { solve problems and/or reach decisions }\end{array}$ \\
\hline
\end{tabular}

\section{Conclusion}

Optimal development in all aspects is the success factor of a future child. Patterns of parenting and education conducted by parents, teachers and the environment will affect the quality of children. Without ignoring other aspects, cognitive development becomes an important focus in addition to physical development in childhood.

Along with the improvement of cognitive abilities, the child begins to realize that the mind is separate from one's object or action. The child can already begin to organize his thoughts in a simple form. Based on Flavel's research, a 3year-old child has the ability to organize his thoughts. This ability is called metacognitive, which is an awareness of our own cognitive, how our cognitive works and how to manage it. This ability is especially important for the efficient use of our cognitive in solving problems. In summary metacognitive can be termed as "thinking about thingking".

Students can use metacognitive strategies in learning include the following three stages: designing what they want to learn; Monitor self-development in learning; And assess what is learned. Metacognitive strategies can be used for any study of any field of study. It is important to direct them in order to consciously control the thinking process in learning.

To improve students' metacognitive abilities, teachers can design learning related to metacognitive ability but are infuse / additional in learning or not separate learning.

\section{References}

[1] Gredler, M.E., 2011, Learning and Instruction: Teori dan Aplikasi, Kencana, Jakarta.

[2] Schunk, Dale H., 2012, Learning Theories: An. Educational Perspective, Pustaka Pelajar, Yogyakarta.

[3] Woolfolk Anita., 2008, Educational Psychology, Active Learning Edition, Pearson Education Inc., Boston.

[4] Gok, T. 2010. The General Assessment of Problem Solving Processes and Metacognition in Physics Education. Eurasian Journal of Physics and Chemistry Education. II(2), 110-112 Hedge
[5] B. \& Meera, B., 2012. How do They Solve It? An Insight into Learner's Practice Approach to Mechanism of Physics Problem Solving. American Physical Society, Physica Review Special Topics, Physics Education Research. 8. 91-109.

[6] Indrayana, I. 2015. Pengaruh Model Problem Solving dan Scaffolding terhadap pemahaman Konsep Fisika Siswa Kelas XI IPA. Jurusan Pendidikan Fisika: Universitas Pendidikan Ganesha.

[7] Kamal, A.A., 2010. 1000 Solved Problems in Classical Physics. Springer: Amerika.

[8] Kuo, V. H., Heller K., \& Heller P. 2015. Physics Faculty Beliefs and Values About Teaching and Learning of Problem Solving II. Physical Review Special Topics-Physics Education Research. 3. 1-11

[9] Rustini, T. 2008. Penerapan Model Problem Solving untuk Meningkatkan Pengembangan Potensi Berpikir Siswa dalam Pembelajaran. Jurnal Pendidikan Dasar.

[10] Selcuk, G. S., Caliskan, S. \& Erol, M., 2007. The Effects of Gender and Grade Levels on Turkish Physics Teacher Candidates Problem Solving Attitude. Journal of Turkish Science Education, 4(1). 92-100.

[11] Sugiyono, 2013. Metode Penelitian Kuantitatif, Kualitatif, dan R\&D. Bandung, Penerbit Alfabeta. 